\title{
Systematic Inventory of the Coleopterological Population of the Rice Plants of Gharb (Morocco)
}

\author{
Karim Berady ${ }^{1}$, Abdelaziz Maqboul ${ }^{1 *}$, Rabia Aoujdad ${ }^{1}$, Mohamed Fadli $^{1}$ and Allal Douira ${ }^{2}$ \\ ${ }^{1}$ Laboratory of Biodeversity and Animal Ressoureces, Ibn Tofail University, Morocco \\ ${ }^{2}$ Laboratory of Botanic \& Protection of Plants, Ibn Tofail University, Morocco
}

*Corresponding author: Abdelaziz Maqboul, Laboratory of Biodeversity and Animal Ressoureces, Ibn Tofail University, B.P 133, 14000, Kenitra, Morocco, Email: maqboul2012@gmail.com



\begin{abstract}
Summary
Due to favorable climatic and soil conditions, Moroccan rice cultivation is practiced in its entirety in the lowest region of the Gharb plain. The systematic study of the colopterological stand at ten stations covering all the rice fields during the two 2015 and 2016 rice seasons revealed that it is very diversified in comparison with other similar environments. Indeed, the latter has 39 species spread over 12 families, with a predominance of species described as a great power of predation and which are of vital interest against the proliferation of living species at the expense of the rice plant. Similarly, the biogeographical analysis of this entomofauna reveals the predominance of the Mediterranean character and the scarcity of other elements of various origins. This in relation with the location of the Gharb plain in an area protected from Saharan influence by the three parallel mountain ranges. Finally, the biotypological study of this colopterological stand during the two cropping seasons allowed the individualization of three groups of species during the phenological cycle of rice: species with summer development; fall-rearing species and species harvested throughout the crop cycle..
\end{abstract}

Keywords: Coleoptera; Systematics; Biotypology; Ecology; Rice fields; Gharb plain

\section{Introduction}

Rice cultivation is considered to be the world's second largest crop in terms of area and production. Indeed, it occupies a floor area of about 160 million hectares with an estimated world production of 598 million tons of paddy per year in 2002 .

In Morocco, rice cultivation is practiced exclusively in the lowest part of the Gharb plain because of the favorable climatic and soil conditions offered by this area as well as the richness of its water network [1]. Currently, the rice potential of this plain is around 4500 hectares [2].

The yield achieved in 2014 is close to 80 quintals per ha, which exceeds that recorded in the countries specialized in this agricultural production. It would even exceed the European average. "It's the only culture where we are better off than most European countries and even the United States."

Because of their purely carnivorous diet, the colopterological stand of rice fields in the Gharb plain (Morocco) is almost entirely of vital interest in controlling the number of organisms living at the expense of the rice plant in particular. aphids, leafhopper nymphs and stem borers, and can thus be described as useful insects in Moroccan rice fields.

The systematic study of this order of insects was carried out on the Moroccan rice fields during the 2015 and 2016 rice growing seasons accompanied by an identification of certain other species which have very close trophic links with the studied group.

\section{Localisation de la zone d'etude (Figure 1)}

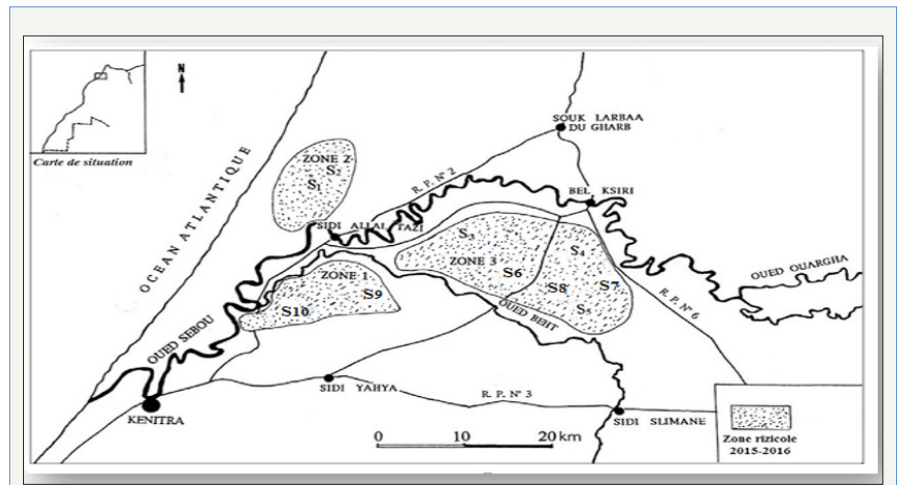

Figure 1: Gharb plain and the study stations location.

The Gharb plain is located in the Atlantic littoral zone between latitudes $34^{\circ}$ and $34^{\circ} 45^{\prime} \mathrm{N}$. Its hydro-geographical area is $7500 \mathrm{~km}^{2}$ [3]. It presents a wide range of soil. Starting from Oued Sebou, we find the Dehs, the Shots and the soils of Merjas respectively. PH slightly alkaline. The climate is Mediterranean. Very rich in water resources (Oued Sebou and its tributaries, Merjas, and groundwater). 


\section{Operation and maintenance of a rice}

The ground works begin in May-April. Rice is sown within 10 days after submersion. The survey period lasts 35 to 40 days. It is only during the month of June that each foot produces many stems (Tallage). Vegetative growth continues in July (Montaison) followed by Flowering at the end of the month and Epiaison in August. It takes 170 days for the rice to reach maturity. The rice field is dry in midSeptember and the harvest is usually in October. The development cycle of this crop takes place between May and October. Since this crop is totally irrigated, it consumes a lot of water. Its field consumption is estimated at $17400 \mathrm{~m}^{3}$ /ha [4]. It corresponds to the compensation of evapotranspiration needs, evaporation of the water body, drainage and infiltration of water into the soil.

\section{Methods of sampling}

Sampling techniques in rice fields are similar to those recommended in shallow environments (ponds) [5-7] and generally adapted in the sampling of helioplankton at rice fields [8]. The idea is to delimit with a hollow cylinder with sharp edges ( $40 \mathrm{~cm}$ diameter during the first two months of submersion in the absence of a macro-intense vegetation and $20 \mathrm{~cm}$ diameter at the rice stage) a volume of water to collect all the fauna present in the water-sludge column.

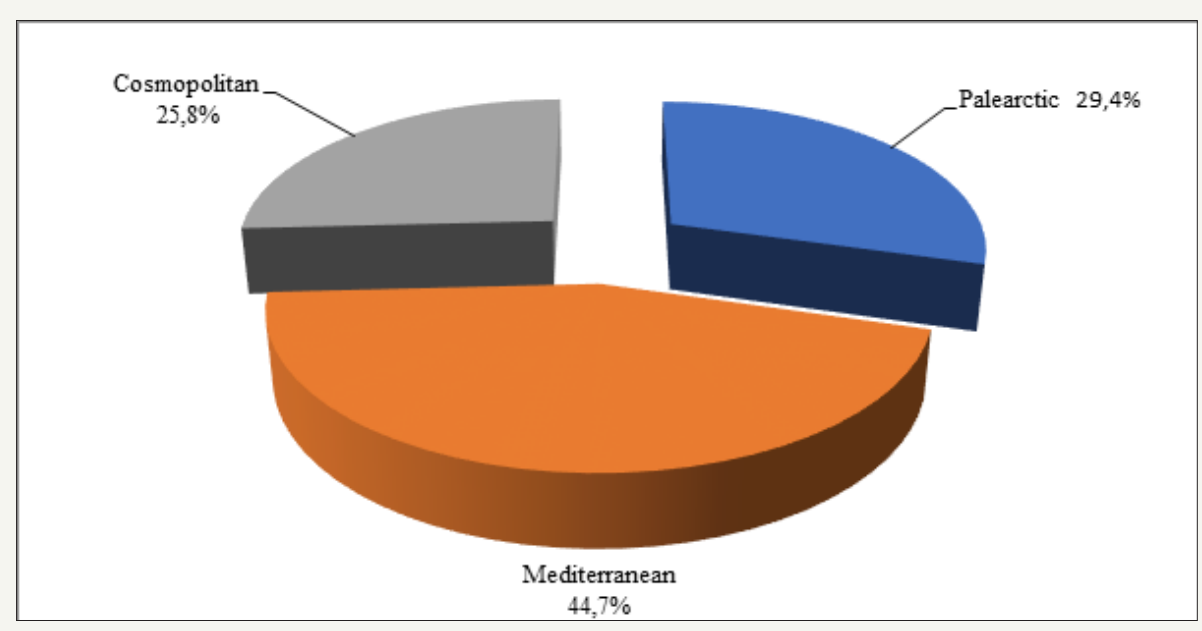

Figure 2: Importance of the main choronological categories of the colopterological stand of the Moroccan rice fields.

The samples are taken from ten stations covering the three rice areas of the Gharb plain during the 2015 and 2016 rice growing seasons (Figure 2). At each station, we made two samples at shallow depths and two others at great depth (edges of the rice field) with a frequency of two monthly readings. So we made qualitative samples using a fine meshed net.

\section{Inventory of harvested species}

After deposition of the chamber in the sediment, its water content is recovered, then filtered using a fine-mesh plankton net $(0.3 \mathrm{~mm})$. Similarly, a slice of sediment or can house Benthic forms are removed and rinsed 2 to 3 times. The filtrate is then stored in a $10 \%$ formalin solution.

Specific determinations were made using original descriptions, European keys and collections from the Rabat Institute of Science (Morocco) (Table 1).

\section{Results and Discussions}

The purpose of this inventory is to enhance taxonomic knowledge of Coleoptera zoological group in Moroccan rice fields. The biodiversity shows that the colopterological group of the Gharb plain rice fields is very diversified in comparison with the number of taxa of the same group harvested in the rice fields of Camargue (France) [9]. These 39 species distributed over 12 families form a banal and classical taxonomic composition of the shallow environments of the littoral zones and the lakes. However there are representatives species typical of this ecosystem, it is the case of the Carabidae, Chrysomelidae, Curculionidae and Coccinellidae.

In addition, among the most faunistic results from this study is the discovery for the first time of a number of taxa that have not been the subject of previous citations. We mention the species of Lissorphopterus oryzophilus, Nanophyses nitidulus and Sitophilus oryzae.

Composition of the entomological Moroccan rice fields based on the choronological categories established by Greca (1964) attributed to each taxon according to its area of occupation [10] shows that it consists essentially by Mediterranean elements (44.7\%), followed by Palearctic distribution (29.4\%) and species with a wide geographical distribution (25.8\%) (Figure 2).

This analysis shows that Mediterranean Europe appears richer than North Africa, both in number of species and number of endemic species. This would be due to the isolation of North Africa from Europe at the end of the tertiary and desertification of the Sahara in the quaternary [11]. These two phenomena have constituted a biogeographic barrier to the fauna of Europe and Africa. These results are similar during the study of the benthic population of the Moulouya watershed [12]. 
Table 1: Summary table of species belonging to the order of coleoptera harvested in Moroccan ricefiels.

\begin{tabular}{|c|c|c|}
\hline $\begin{array}{c}\text { Suborder: Adephaga }=\text { Coleoptera } \\
\text { Hydrocanthares }\end{array}$ & $\begin{array}{l}\text { Family: Dytiscidae } \\
\text { Family: Noteridae } \\
\text { Family: Haliplidae } \\
\text { Family: Gyrinida } \\
\text { Family: Carabidae. }\end{array}$ & $\begin{array}{l}\text { - Hydrovatus clypealis SHARP, } 1876 \\
\text {-Yola bicartina LATREILLE, } 1804 \\
\text {-Guignotus pusillus FABRICIUS, } 1781 \\
\text {-Laccophilus minutus LINNE, } 1758 \\
\text {-Laccophilus hyalinus DE GEER, } 1774 \\
\text {-Rhantus pulverosus STEPHENS, } 1828 \\
\text {-Ertes stictucus LINNE, 1767 } \\
\text {-Dytiscus pisanus CASTELNAU, } 1834 \\
\text {-Cybister lateralimarginalis DE GEER, } 1774 \\
\text {-Copelatus atriceps SHARP, } 1880 \\
\text { - } \text { - Noterus leavis STURN, 1834. } \\
\text {-Pletodytes caesus DUFTSCHMID, } 1805 . \\
\text { - Gyrinus substriatus STEPHENS, } 1828 . \\
\text {-Calatus ambiguus PAYKULL, } 1790 . \\
\text {-Harpalus affinis SCHRANK, } 1781 . \\
\text {-Pseudoophonus rufipes DE GEER, } 1774 . \\
\text {-Poecilus cupreus LINNE, } 1758 . \\
\text {-Anchomenus dorsalis PONTOPPIDAN, } 1763 . \\
\text {-Carabus auratus LINNE, 1761. } \\
\text {-Brachinus sp. WEBER, 1801. } \\
\text {-Pterostichus melanarius ILLEGER, } 1798 .\end{array}$ \\
\hline \multirow[t]{2}{*}{ Suborder: Polyphaga=Coleoptera Palpicornes } & $\begin{array}{l}\text { Family: Hydraenida } \\
\text { Family: Helophoridae } \\
\text { Family: Hydrophillidae } \\
\text { Family: Curculionidae }\end{array}$ & $\begin{array}{l}\text {-Ochtebius sp. Leach, } 1815 . \\
\text {-Helophorus aquaticus LINNE, } 1758 . \\
\text {-Berosus hispanicus KUSTER, } 1847 . \\
\text {-Berosus suturalis KUSTER, } 1844 . \\
\text {-Léocharès lividus FORSTER, } 1771 . \\
\text {-Enochrus affinis THUNBERG, } 1797 . \\
\text {-Enochrus fuscipennis THOMSON, } 1884 . \\
\text {-Paraccymus aeneus GERMAR, } 1824 . \\
\text {-Celostoma hispanicum KUSTER, } 1848 . \\
\text {-Cercyon sp. LEACH, } 1817 . \\
\text {-Lissorhoptrus oryzophilus KUSCHEL, } 1951 .\end{array}$ \\
\hline & $\begin{array}{l}\text { Family: Elmidae } \\
\text { Family: Chrysomélidae } \\
\text { Family: Coccinelidae }\end{array}$ & $\begin{array}{l}\text {-Nanophyes nitidulus GYLLENHALL, } 1838 . \\
\text {-Sitophilis oryzae LINNE, } 1763 . \\
\text {-Oulimnius maurus BERTHELEMY, } 1979 . \\
\text {-Timarcha scabripennis LATREILLE, } 1839 . \\
\text {-Lachnaia octomaculata PIC, } 1895 . \\
\text {-Chaetocnema sp. STEPHENS, } 1831 . \\
\text {-Coccinella septempunctata LINNE, } 1758 .\end{array}$ \\
\hline
\end{tabular}

In addition, interspecific relationships based on bibliographic data reveals the predominance among this population of predatory species that are characterized by active behavior, which allows them to hunt large numbers of prey. Except of Imagos of Hydrophilidae and Haliplidae, Coleoptera chrysomelidae and Curculionidae are considered phytophagous [5,13-20] which the majority of species have carnivorous habits. So they can fight against the outbreaks of organisms that can cause damage to this crop. Thus, these predators can be considered as aids to this crop, and therefore contribute to biological control that occurs spontaneously in the rice field, especially in places where there is no use of a wide range of pesticides. In addition, many species among this group have a mixed diet, which ensures greater diversity and stability in the community.

In order to look for the spatio-temporal evolution of the Coleopopera population of the Moroccan rice fields during the two rice seasons 2105 and 2016, we used the correspondence factorial analysis (CFA). This statistical method is widely used, by several authors [7,8,21-23] to analyze the structuring of lentic and lotic environments.

Distribution of the species subjected to this multivariate analysis highlights the individualization of three main groups of species around the factorial plane F1 x F2, which are organized in a continuum in the same direction as the seasonality gradient. statements. This analysis shown the presence of species with summer and automnal development and spreading species along the culture cycle (Figure 3).

\section{Group I: Species with summer development}

This is the case of Dytiscidae E. sticticus known for its great carnivorous power, frequenting calm waters rich in aquatic vegetation $[13,24]$ and with an abundance of soft prey composed mainly of larvae of Diptera chironomidae. 
Other species in this group P. caesus and P. aeneus are considered as phytophagous [25], in particular at the larval stage which are most often associated with the characeae in addition to their preference for waters with high mineralization rates, especially for P. aeneus [16,25].

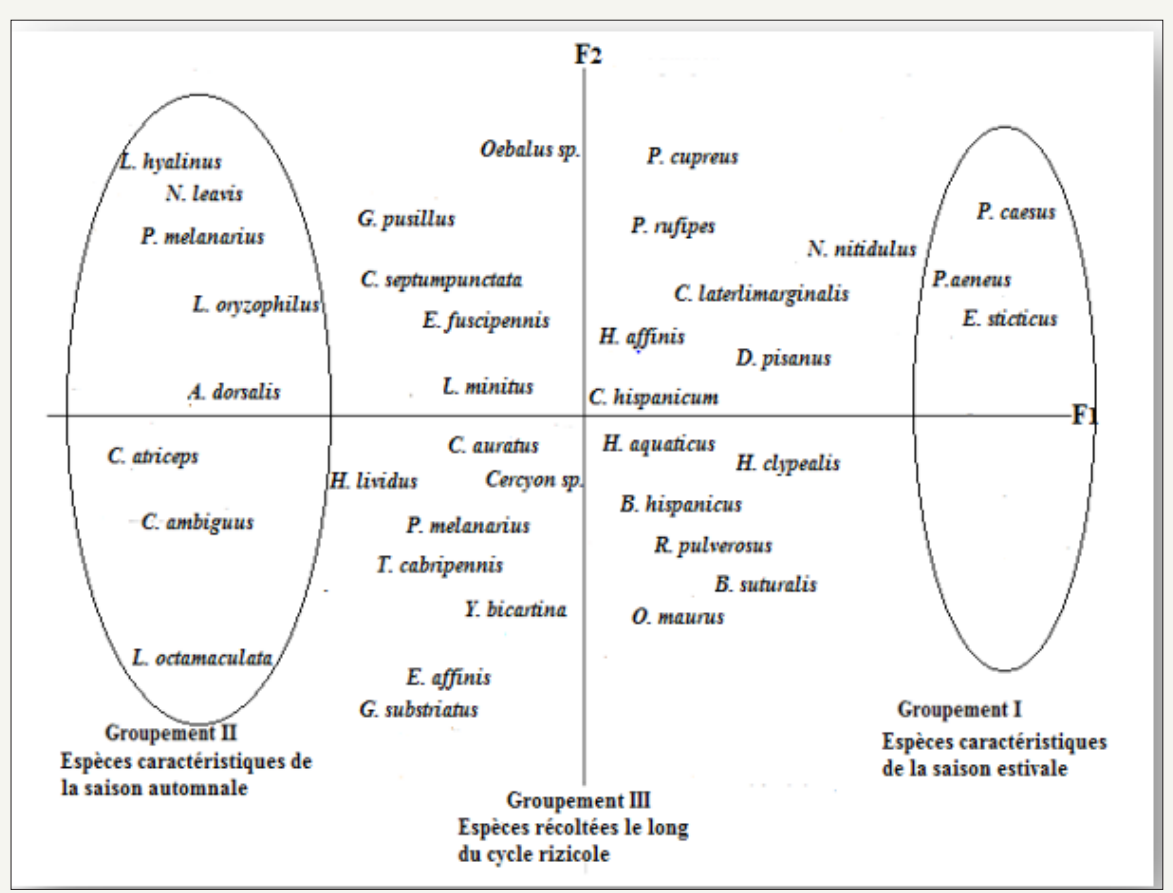

Figure 3: Biotypology of rice fields: structure of the cloud-species in the factorial plane F1 X F2.

\section{Group II: Autumnal species}

For the colopterological population, we can highlight a first group represented by the Coleoptera hydrocanthares (C. atriceps, L. hyalinus, N. leavis, C. ambiguus, A. dorsalis, P. melanarius). They are described as an excelent predators of aphids, leafhopper nymphs and stem borers which abound during this period, in addition to their preference for areas rich in aquatic vegetation and decomposing organic matter, particularly for representatives of the family Carabidae and the Dytiscidae [5,25-27]. The second group is represented by the species L. oryzophilus, considered as phytophagous, devastating plants of rice [28]. According to the Chrysomelid (L. octamaculata) compared to its highly polyphagous behavior [29], its presence at this stage would be related to the abundance of prey of all kinds at that time.

\section{Group III: Species with spreading development throughout the rice season}

Between these two characteristic groups of the summer and autumn season distribution, many species are usually present throughout the rice field practice. This intermediate group is constituted by the Coleoptera hydrocanthares which are known as voracious carnivorous predators. The primary consumers who serve them as food are in direct relation with the vegetable biomass of the rice fields $[5,13]$. It therefore seems obvious to relate their presence to certain types of plants, especially those that will directly serve as food such as filamentous algae, characeae and probably Oryza sativa present throughout the rice cycle. This plant cover also plays a supporting role for these species which are bad swimmers.

On the other hand, N. nitidulus is known by its plants pest, especially at the stem part of the plant [30]. the ladybug C. septempunctata, well known for its use in biological control, because it is predatory in the larval and adult stages [20]. Its prey are the small insects: Aphids, Mealybugs, Whiteflies, Diptera and Lepidoptera larvae (caterpillars). They can also eat insect eggs [31]. They are therefore entomophagous predators, active during the day and frequenting the top half of the rice plants.

Finally, 0. maurus is considered as characteristic of lotic environments of freshwaters [12]. Its presence in the rice fields is linked to the phenomenon of the natural drift of these organisms from irrigation water, where the favorable conditions for its reproduction are meeting.

\section{Conclusion}

The taxonomic study of the Coleopterological group of the rice fields of the Gharb plain (Morocco) shows that it is very diversified in comparison with other similar environments despite of the short period of the rice cycle. This agricultural ecosystem has 39 species spread over 12 of the most representative families of this group. It is essentially composed by Mediterranean taxa, followed by species whose distribution extends to the Palearctic domain and finally species with a wide geographical distribution. On the other hand, due to their pronounced predatory power, most of the listed species contribute to a significant biological control by controlling 
the outbreaks of insects harmful to rice.

The biotypological study has highlighted the individualization of three main groups of species around the factorial plane F1/ F2: summer-growing species grouped on the positive pole of the F1 axis; species with autumnal development, distributed on the negative pole and finally the grouping of spreading species along the culture cycle.

\section{References}

1. Anonyme (1970) Atlas du bassin de sebou. p. 143

2. Anonyme (1974) Rice report of the O.R.M.V.A.G. ministry of agriculture and agrarian reform. p. 13.

3. Combe E (1969) Hydrogeological map of the gharb plain $1 / 100000$. Morocco, p. 39.

4. Lahlou O (1989) Rice growing in Gharb: Current situation and prospects. Report of the study day on the contraints related to Moroccan rice cultivation and current methods of genetic improvement of rice.

5. Ramdani M (1981) Hydrobiological research on the Merja deSidi Boughaba (Atlantic coast of Morocco), Physico-chemiquai study and faunistic analysis. Bull Inc Sc Rabat 5: 73-133.

6. Himmi O (1991) Culicidae (Diptera) from Morocco. Updated key of determination and study of the dynamics and the biological cycles of some populations of the Rabat-Kenitra region. Thesis $3{ }^{\text {rd }}$ cycle, Univ Med V Rabat, Morocco, p. 185.

7. Berady K (1997) Bio-ecological research on the entomological settlement of rice fields in the gharb plain (Morocco). Thesis of $3^{\text {rd }}$ cycle, Univ Ibn Tofail, Kenitra, Morocco, p. 158.

8. Aoujdad R (1996) Ecological and systematic research on cladoceran crustaceans from the gharb plain (Morocco). Thesis of $3^{\text {rd }}$ cycle, Univ Ibn Tofail, Kenitra, Morocco, p. 135.

9. Viala M (1978) First elements of macrofauna stand and Odonata (Ischnaura elegans) populations in shallow environments. DEA, USTL, Montpelier, USA, p. 56.

10. Aukema P, Reiger C (1995) Catalogue of the heteroptera the palaearctic region. The Netherlands Entomlogical Society 1: 222.

11. Louanci A (2014) $4^{\text {th }}$ Franco-maghrebian congress of zoology and $5^{\text {th }}$ Franco-tunisian days of zoology Korba-Tunisia.

12. Lamri D, Hassouni T, Loukili A, Belghyti D, Chahlaoui A (2016) Contribution to the knowledge of coleoptera (Coleoptera) of the moulouya hydrographic network (Morocco). Faunistic Entomology 69: 97-109.

13. Aouad N (1984) Ecological study of hydrophiloidae of stagnant waters of the rabat region (Coleoptera: Palpicornes). Thesis $3^{\text {rd }}$ cycle, Univ Paul Sabatier, Toulouse III, France, p. 149.

14. Aguilar RM (2000) Intro production of aroz in southern Spain. p. 320

15. Aguilar RM (2001) Research strategies for development in transition economies. Mediterranean options notebooks. pp. 123-126.

16. Queney P (2005) French maritime locations, new or confirmed, for hygrotus (Coelambus) nigrolineatus (STEVEN, 1808) and Pallidulus (AUBE, 1850), Metaporus meridionalis (AUBE, 1838), Octhebius bifoveolatus (WALTL, 1835) (oleoptera: Dytiscidae and Hydraenidae) The Coleopterist 8(2): 138-139.
17. Meurgey F (2011) The continental arthropode of guadeloupe: bibliographical synthesis for a state of the places of knowledge. SHNLH report for the national park of Guadeloupe, France, p. 184.

18. Delobel M (2012) The presence in belgium of dieckmanniellus nitidulus (GYLLENHAL, 1838) (Coleoptera: Curculionoidae Nanophyidae) and the key to identification of nanophyidae species. Faunistic Entomology 65: 105-117.

19. Essakhi D, El harchli EH, Benjelloun M, Maazouzi M, Mansouri I, et al. (2015) Contribution to the study of the diet of Orthoptera Locusts in the Middle Atlas (Morocco). International journal of engineering and science 5: 60-66.

20. Rafarasoa LS, Ranarilalatiana T, Andrianantoandro A, Ravaomanarivo LH (2015) Biodiversity of the entomofauna of rice paddies in the alaotra lake region (Madagascar). Malagasy Nature 9: 15-38.

21. Dakki M (1986) Hydrological research on the upper sebou (Middle Atlas): A contribution to the faluna, ecological and historical knowledge of the south-mediterranean waters. Thesis Doct State Univ Med V, Rabat, Morocco, p. 214.

22. Fekhaoui M (1990) Hydrobiological researches on the upper sebou subjected to the discharges of the city of Fez; followed by macropollution and assessment of its richness on the physical, chemical and biological components of the ecosystem. Thesis Doct State Univ Med V, Rabat, Morocco, p. 173.

23. Maqboul A (1996) Biological and ecological research on the malacological fauna of the plain of gharb (Morocco). Thesis $3^{\text {rd }}$ cycle, Univ Ibn Tofail, Kenitra, Morocco, p. 157.

24. El alaoui AMA (1985) Contribution to the ecological study of coleoptera hydrocanthares of the moroccan coastal meseta. Thesis $3^{\text {rd }}$ cycle, Univ Med V, Rabat, Morocco, p. 171.

25. Bloechl A, Kahneman S, Philipi B, Melbert A (2010) Abundance, diversity and succession of aquatic Coleoptera and Heteroptera in a cluster of artificial ponds in the North German Lowlands. Limnologica-Ecologiy and Management of Inland Waters 40(3): 215-225.

26. Cojocaru I, Popescu IE (2004) At the diversity of Coleoptera aquatiques (Insecta, Coleoptera) of the marais of cows (Bucarest). Scientific Annals of the University, Animal Biology, pp. 77-83.

27. Baranovska J, Knapp E, Saska P (2014) The effects of everwintering sex, year, field identity and vegetation at the boundary of fields on the body condition of Anchomenus dorsalis (Coleoptera : Carabidae). Eur J Entomol 111(5): 608-614.

28. Lupi D, Colombo M, Giudici ML, Villa B, Sparacino AC, et al. (2007) Present status of knowledge on Lissorhoptrus orysophilus. 4éme inetrnational Temperate Rice Conference 2007: 138-139.

29. Beenen R, Roques A (2010) Leaf and seed beetles (Coleoptera, Chrysomelidae). In: Roques A, Coll (Eds.), Alien terrestrial arthropods of Europe. Biorisk 4(1): 267-292.

30. Hemptine JL, Magro A, Majerus M (2005) Ladybugs, description, cohabitation, observation. In: Delachaux, Nestle (Eds.), Paris, France, p. 192.

31. Magro A, Le compte E, Magne F, Hemptine JL, Crouau-roy B (2010) Phylogeny of ladybirds (Coleoptera: Coccinellidae) are the subfamilies monophyletic. Molecular phylogenetics and evolution 54(3): 833-848. 
Creative Commons Attribution 4.0

International License

For possible submissions Click Here

Submit Article

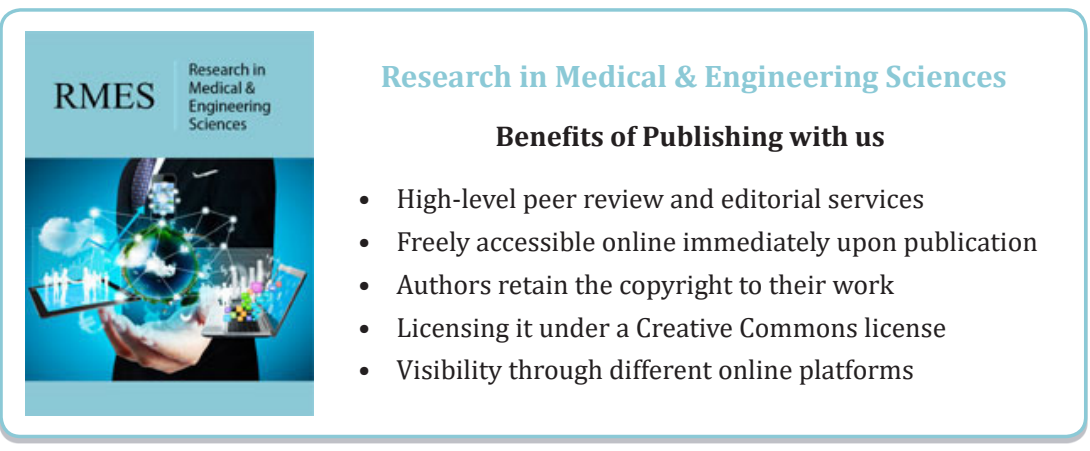

